\title{
The sophisticated literacy practitioner and the global pandemic
}

\author{
Lynn Downes $^{1}$ (]) Deb Brosseuk ${ }^{2}$ ()
}

Received: 14 September 2020 / Accepted: 30 March 2021 / Published online: 19 May 2021

(C) The Australian Association for Research in Education, Inc. 2021

\begin{abstract}
Negative portrayals in the Australian media situate teachers as a problem and teaching as a deficit practice. Society is positioning teachers, especially teachers of literacy, as the reason for poor student performance. In addition, negative media discourse around deficit initial teacher education, especially with regard to the teaching of reading and writing, is adding to the overall assumption that teachers of literacy are failing. This article highlights instances of teacher practice by literacy teachers during the global pandemic of COVID-19 which oppose the 'problem teacher' discourse. Snowball sampling was used to garner seven early years and primary school teachers for interviews, focussing on teacher perceptions of multimodal texts. A Foucaultian lens of governmentality and power and Fairclough's approach to Critical Discourse Analysis (CDA) were used as lens and method of analysis. The findings of this study indicate that these participant teachers have been sophisticated practitioners in their planning and practice during the pandemic, despite the institutional barriers and extreme disruptions experienced. On reflection, therefore, the constructed societal discourse around 'problem teachers' needs to be reviewed and adjusted.
\end{abstract}

Keywords Literacy teachers - Sophisticated practitioners - Extreme disruptions . Global pandemic · Critical Discourse Analysis · Literacy practice

Lynn Downes

12.downes@qut.edu.au

Deb Brosseuk

debbie.brosseuk@sydney.edu.au

1 Faculty of Education, Queensland University of Technology, School of Teacher Education and Leadership, 149 Victoria Park Road, Kelvin Grove, QLD 4059, Australia

2 Faculty of Arts and Social Sciences, Sydney School of Education \& Social Work, The University of Sydney, Room 429 Education Building A35, Sydney, NSW 2006, Australia 


\section{Introduction}

Teachers and teaching have been devalued in society along with the tendency to hold teachers responsible for all that is wrong in society (Freire, 2009). Negative portrayal of schools, school leaders and teachers contribute to this discourse which situates teachers as the 'problem' in education systems (Baroutsis, 2016). In addition, media reports normalise defective and negative understandings of teachers and schooling which are then projected as "taken for granted" or "common-sensical" perceptions about education. These perceptions consequently build and perpetuate the ideology (Baroutsis, 2015, p. 614).

It is with this knowledge in mind that the current paper originated. The data from this paper emanated from a larger study which happened to coincide with the COVID-19 global pandemic and associated forced quarantine of many around the world. The original study was focussed on teachers' perceptions of multimodal texts, and interviews were arranged with teachers, via the online communication platform Zoom, to discuss multimodal text use in the early years and primary years of schooling in Australia. During the interviews, it was apparent that COVID-19 was having an impact on teacher practice which opposed the 'problem teacher' discourse discussed earlier. This paper is the result of those findings which demonstrate that the literacy teachers interviewed are sophisticated practitioners, especially when working under extreme conditions.

The paper begins with a discussion on negative discourses in the media concerning teachers and moves on to elaborate on negative media about teachers of literacy. ${ }^{1}$ Extreme disruptions in education contextualising the global pandemic - COVID-19 are discussed, and the authors further particularise the study with discussion around Foucault and his thoughts on power and governmentality. The design of the study is examined including methods of analysis outlining Fairclough's approach to Critical Discourse Analysis (CDA) and how it was used. The paper then articulates the findings and ends with the discussion.

\section{Negative discourses and the media}

Negative discourses about professional teachers and their performance are repeatedly, but not always, reported by actors external to education and within the media (Edling, 2015; Mockler, 2020). These negative discourses are problematised by the media as viewing education in a permanent state of crisis; as acting as spokesperson for teachers but excluding teachers'/educators'/educational researchers' knowledge and experiences and stereotyping the 'good teacher' while overlooking the task and relational complexities that go along with the roles (Edling, 2015). Media in this instance refers to various channels through which public information is

\footnotetext{
1 At the outset and as caveat the authors are not taking the stance that all teachers are perfect; in addition, the authors acknowledge that media commentary is often politically motivated by interests separate from education and its stakeholders. The authors explore and highlight this commentary without adding to the negative rhetoric.
} 
disseminated, such as television, radio and the press, and taking the form of "news, documentary, magazine programs, dealing with politics, social affairs, science and so forth" (Fairclough, 1995, p. 2). Power exists within media and its dissemination of information being able to construct certain ideologies that include and exclude depending on how they are positioned (p. 14).

Narratives of distrust and performance in editorials about education in the Australia media are evidenced: Distrust of teachers, their unions, principals and school bureaucrats; performance of students, teachers and schools, with the associated judgement of underperformance through comparison (Mockler, 2013). Mockler reported the narrative of distrust outweighs that of performance in the editorials she surveyed. Similarly, more recent research suggests that $71 \%$ of teachers in Australia feel underappreciated by society (Heffernan et al. 2019). The same study reveals that teachers (n2444) want the public perceptions of teachers and teaching to be improved, furthermore adding that they want the public to trust them to do their jobs.

In opposition to the negative discourse in the media regarding teachers, the abovementioned study found evidence of some positive regard for teachers. The nationally representative sample of the public (n1082) perceived that teachers are both respected (63\% moderately respected and 19\% well respected) and trusted (60\% moderately trusted and $33 \%$ trusted).

Similarly, an online survey was conducted with parents (n803) from New South Wales, Queensland and Victoria regarding their perceptions of home-based learning during the pandemic (Fahey \& Joseph, 2020). The results show 55\% of surveyed parents had a more positive opinion of teachers than previously documented; however, rural and regional parents show concern for the quality of curriculum and educational standards. Fahey and Joseph stress that the improved opinion of teachers by parents "has clearly lifted due to home based learning" (p. 14). Despite these reflections of public perception, however, this positive discourse fails to garner as much attention in the media as its negative counterpart.

\section{Negative discourses and teachers of literacy}

A prominent negative discourse in the media is the discourse on literacy. As in many other countries, literacy education in Australian schools has long been an area for contested accounts of what should be the correct teaching methods to enable and ensure effective learning (Cope \& Kalantzis, 2000). In viewing education as an economic priority rather than a social one, agendas for schooling systems are being set up as prominent areas for governments to demonstrate their improvements of overall standards. Literacy has become a focus of critique of stakeholders in education areas, particularly as results of standardised testing are published and deliberated (Thompson, 2016). Publication of data from these standardised testing practices is accompanied by negative suggestions about teacher performance as the cause of poor student performance (Moss, 2016, p. 508). For example "Young kids better on reading, but writing skills are falling" includes comment from Blaise Joseph, a research fellow at the Centre for Independent Studies, saying "Having something 
like NAPLAN allows teachers and parent [sic] to identify early on if their child is falling behind or not being taught well [emphasis added]" (Bolton, 2019b, para 6).

In addition, media depiction of factors such as teacher accountability for student outcomes (Tuinamuana, 2011) and the ongoing and growing rhetoric about how best to teach reading and writing (Department of Education Tasmania, 2016) - alongside the negative media discourse around deficient initial teacher education relating to the teaching of reading and writing - add to the negative and contested accounts and discourses around literacy teaching, teachers and their practice (Literacy Baroutsis \& Woods, 2019; Literacy Educators, 2019). For example, in the article, "Boys' inability to write clearly is a new crisis in education", Peter Goss, the program director for school education at the Grattan Institute, states, "It's very hard to get any visibility into how writing is taught in classrooms". This clearly references poor NAPLAN writing outcomes related to teacher practice. (Bolton, 2019a, para 11). Similarly, Baker, 2020, "Writing wrongs: 'Our society is about to hit a literacy crisis" and "The epidemic Australia is failing to control" which declares Australia has an "education epidemic' (Sahlberg, 2021) add to the rhetoric.

Student performance therefore also becomes a key component of the rhetoric. Due to the decline of Australian students' performance on both national and international literacy assessments, the Australian Government commissioned a panel of experts in 2017 to provide insight into how to improve Australian student school achievement and performance (Australian Government, 2018). Their recommendations in 'Through growth to achievement' included, amongst others; personalised learning and teaching based on the child's needs and creating the conditions to enable teachers and schools to successfully adopt teaching practices such as collaborative planning. Furthermore, the panel recommended that schools and school systems need to adapt to changing contexts and needs, and to strengthen the attractiveness of teaching as a profession. To support this, conditions and culture need to be created to enable more professional collaboration, feedback, mentoring and observation amongst teachers, and to provide teachers with high-quality professional learning.

\section{Extreme disruptions: the pandemic}

Constant disruptions are part of the teaching landscape and impact upon teacher practice, literacy learning and teaching as well as standardised testing results (Thomas et al. 2019). Epidemic-related school disruptions and interruptions impact educational attainment for students with long-term consequences (Meyers \& Thomasson, 2020). The first cases of coronavirus (COVID-19) in Australia were detected in January 2020 (Australian Government, 2020). The virus originated in mainland China and quickly spread worldwide causing the World Health Organisation (WHO) to declare a global pandemic in March 2020 (2020). Many countries in the world supported mass lockdowns, cancellation of planned social events and ultimately quarantine for their citizens, in an effort to stop the spread of the virus and to keep their citizens safe. Global education has been impacted by the pandemic with schools closing in 107 countries including Australia (Viner et al. 2020), potentially impacting 862 million children and young people (United Nations Educational 
Scientific \& Cultural Organization, 2020). Paradoxically, the disruption brought the professional expertise of Queensland teachers into focus, creating the possibility of a counter discourse.

\section{Linking negative discourses and Foucault - conceptualising the study}

Foucault provides a lens for examining how the reality of teachers' sophisticated professional practices opposes the negative discourses presented in the media. The strength of Foucault's theory clearly links media portrayal, truth/knowledge and power. Foucault, as the architecture of discourse, defines discourse as,

a certain way of speaking, a group of verbal performances that produced by the groups of signs, formulations, a series of sentences or propositions, the group of statements that belong to a single system of formation, incorporating not only what is said, but things unsaid... in a system of prohibitions and values, in a space in history. (1972, pp. 107,110,193)

Each society has its own system of 'truth', according to Foucault (1980), and there are certain discourses that make up that 'truth' - 'regimes of truth' (Foucault, 1975). These discourses are procedures, 'mechanisms' or techniques put in place and agreed upon as 'true' with specialised people assigned status to verify what counts as 'true'. These discourses and regimes of truth are linked very closely with power - "by a circular relation to systems of power which produce it and sustain it, and to effects of power which induces and which redirect it" (Foucault, 1977, pp. 13, 14). The abovementioned negative media discourses about teachers can be viewed as current 'regimes of truth'; the media and other members of society, parents, the education department and so forth, as the systems of power that produce and sustain these discourses.

Power relations between individuals only exist when put into action - "an action upon an action" (Foucault, 1982, p. 220). In order for the relationship of power to work, the person being controlled recognises and maintains the relationship. Furthermore, a host of possible interventions, reactions, responses and results are achievable in the 'power relationship'. As example, negative media discourses and decline in student performance result in government recommendations such as 'Through growth to achievement' mentioned on page 5.

Ultimately though, power is situated in social networks where there is differentiation - differentiation in relation to privilege, status, economic differences, differences determined by law or tradition, knowledge and so forth - power is therefore conditional upon and products of these differentiations (Foucault, 1982). However, power for Foucault is not always negative and oppressive, it can be productive and generate knowledge and cultural order (Foucault, 1978). Power is capillary, it "reaches into the very grain of individuals, touches their bodies and inserts itself into their actions and attitudes, their discourses, learning processes and everyday lives" (Foucault, 1980, p. 39).

Power/knowledge and control moves to the individual via 'governmentality' where there is "contact between the technologies of domination of others and those 
of the self" (Foucault, 1988, p. 19). Accountability and responsibilisation are ways to discipline people and institutions, which includes self-discipline and self-reflection (Rose, 1999). The subject is constituted through practices of the self which are modelled by the society, social group and/or culture that surrounds them - the discourses of their time (Foucault, 1997). These constructions are ever-changing, even when attached to the same individual, where different situations result in different relationships of the subject to the subject.

A further key Foucaultian concept concerns the modes used to transform human being into subjects. The modes are, first, the objectivising of the subject through inquiry such as classifying, analysing, normalising and disciplining. An example of this would be the naming and subject positioning of people, in this case teachers in the media being labelled and classified as 'good' or 'bad'. The analysing takes place with standardised testing and in the media; the teachers reflecting good results are 'good teachers' whereas the teachers with bad results are labelled - classified - as 'bad teachers'. This is all normalised in the media and those teachers who do not follow with the 'classification' are disciplined, either in public discourse or by the education department/school administration and so forth. Second, the objectivising of the subject occurs through practices of dividing and this can be a division from others or a division within the subject themselves. As an example, the division between the 'good' teacher vs 'bad' teacher - 'good teachers work hard; bad teachers are lazy' (Alhamdan et al. 2014). The third mode by which human beings become subjects is through self-regulation and self-inspection.

The three technologies of the self that Foucault identifies are: first, self-examination with respect to thoughts relating to reality; second, self-examination in relation to rules and third, self-examination with respect to "the relation between the hidden thought and inner impurity" (Foucault, 1997, p. 247).

\section{Methods and analysis}

As mentioned earlier, the data for this paper emanated from a larger study focussing on teacher conceptions of multimodal texts in classroom practice. The larger study forms part of ongoing collaborative research between two Australian universities with ethics approval received from the Queensland University of Technology prior to data collection.

Seven teachers from primary school and early years education contexts in Australia were interviewed for approximately $45 \mathrm{~min}$ each. In the Australian context, the early years extend from birth to Year 2 and primary extends from Year 3 to Year 6. We chose this age group because literacy instruction is so important during this time (Comber et al. 2002). Informed written and verbal consent was obtained from each participant. Snowball sampling was used to garner participants purposefully, as a type of "convenience sampling" (Heckathorn, 2011, p. 357), in order to achieve a broader reach into teaching communities in Queensland. The semi-structured interviews were conducted from May through June 2020, during the height of the COVID-19 isolation measures. They were recorded on the cloud-based virtual 
communication platform Zoom, which enabled the participant teachers to interview safely, taking the isolation issues into account.

To set context, in Australia, individual states and territories were permitted by the Federal Government to decide how schools, in their own areas, would operate throughout the nation-wide pandemic restrictions. In Queensland where the study took place, schools remained open for those students of essential workers such as medical workers, grocery store workers and delivery truck drivers, amongst others. All other students in Queensland were required to work from home. The Education Department supplied 'online remote learning' learning@home (Queensland Government, 2020) options to support these students. All seven participants from this study engaged in both face-to-face classroom teaching as well as remote/online teaching during this time.

Fairclough's approach to Critical Discourse Analysis (CDA) was employed as the analysis technique and uses a combination of language analysis, 'text-and-interaction' and a social-theoretical aspect of discourse (Fairclough, 1992). Fairclough uses the term discourse "very similar to how Foucault uses discourse" (Fairclough, 2004, p. 11), as language-in-use; as an element of social life and as language that is interconnected with other elements; and in an abstract way of representing aspects of the world (Fairclough, 2003). The 'critical' aspect aims at highlighting hidden connections between power, language and ideologies within discourse as well as the constructive effects of discourse on social identities, systems of knowledge, beliefs and social relations (Fairclough, 1989).

The choice of fusing Foucault and Fairclough may seem unsuitable to some because Fairclough positions himself as a Marxist, while Foucault refused to commit to any particular position (Fairclough, 2004; Foucault, 1998). Fairclough also focusses more in-depth on textual or linguistic focussed analysis while Foucault's approach is more abstract and socially oriented (Fairclough, 1992). Fairclough does acknowledge Foucault's approach to discourse analysis and uses his work to 'heavily inform' his own approach (Dremel, 2014). The solution to this combination is with the analysis itself. Foucault directs his approach more toward discursive practices, the rules of formation that define possible subjects or objects of knowledge and of the possibility of discourse (Foucault, 1972). His emphasis is on the capacity to conceptualise knowledge and power and of the relationships between the discursive and non-discursive. Fairclough's addition of real examples including text and context allows opportunity to show wider social processes (Fairclough, 2001) - "the social practice quality of discourse" (Dremel, 2014, p. 157) and hence why it was used in this analysis.

As a precursor to discussion about the findings, it is important to backdrop what the focus was in different areas when analysis occurred. Fairclough differentiates between three dimensions of meaning in a given text. These are:

Action or Genres - this defines ways of acting within a social event and how a text contributes to and situates within social action and interaction; for example, how teachers function within the social action and interaction of school, home, resources and policy during the pandemic. To analyse this dimension, Fairclough advises looking at semantic and grammatical relations between sentences and clauses amongst other things - looking at conditional, temporal, contrastive or concessive 
relations, elaboration and additive relations that are both 'local' in the text as well as 'global'. The analyst focusses on types of exchanges as well as grammatical mood and so forth (Fairclough, 2003).

Representation or Discourses - ways of representing certain aspects of the world and different perspectives of the world through the use of language. Here the analyst focusses on aspects such as hyponymy (meaning inclusion), synonymy (meaning identity) and antonymy (meaning exclusion) - Fairclough's terminology - as a way of 'lexicalizing' the world. Things like collocations, patterns of words, words that precede and follow on, use of metaphors and assumptions, amongst other things, determine Discourses (Fairclough, 2003).

Identification or Style - ways of being or identities which are linked to how individuals speak and use language. Here the analyst will concentrate on things like evaluation, mood, predictions, modality and exchange types as well as phonological features such as intonation, rhythm, stress, pronunciation, vocabulary use and the interplay between body language and language (Fairclough, 2003). The ability to record body language and reactions such as facial expressions and hand gestures was facilitated by zoom recordings which aided analysis in this area.

\section{Analysis and findings}

The data from this study demonstrate that despite tensions regarding institutional boundaries and extreme conditions experienced during the global pandemic, the participants in this study are sophisticated literacy practitioners. The findings are discussed under the following sections: teacher confidence and the division of self; learning new ways of communicating; collaborative learning versus the institution - us vs them and last, power inequities.

\section{Teacher confidence and division of the self}

When talking about their teaching practice and decisions regarding literacy planning and implementation during COVID-19, the teacher participants' knowledge and confidence in practice is demonstrated in their language use. A juxtaposition occurs in language use when participants discuss definitions earlier in the interviews which highlights their uncertainty. Data showing uncertainty about definitions, theories and some terms is evident when participants use modality in their language use. However, when talking about decisions, planning and practice during COVID-19, participants use more direct language choices which demonstrates their confidence in decision making.

Early in the interviews, the researchers asked questions relating specifically to definitions and knowledge about multimodal texts and multimodality. Participants used responses containing modality such as might, may, and probably and mental processes. Mental process clauses such as I think, I feel, I guess, and markers of modalisation show uncertainty (Liu \& Fox Tree, 2012). Hedging devices such as these are used when the speaker is not confident in their response (Lakoff, 1975). 
Table 1 Language use: uncertainty vs confidence

\begin{tabular}{|c|c|}
\hline Modalisation in language use & Statements with limited to no modality \\
\hline don't know what the word is... so it might be & $\begin{array}{l}\text { so we provided a grid of activities for the week } \\
\text { which was just emailed out to the parents }\end{array}$ \\
\hline I may be wrong here but & I just uploaded it \\
\hline ummm... I'm probably going on a tangent here but & $\begin{array}{l}\text { I had audio on OneNote. So I made sure that I did } \\
\text { the audio as well, because they needed to hear } \\
\text { my voice }\end{array}$ \\
\hline I think, that's my take on it anyway & well, I already use Google classroom \\
\hline that's what I think it is & it was a really good way of connecting all the kids \\
\hline $\begin{array}{l}\text { I think, yeah, so instead of, I believe. Anyway.... } \\
\text { I'm not sure }\end{array}$ & we are going to use them as a tool in the future \\
\hline I'm pretty sure, I'm pretty positive & $\begin{array}{l}\text { I'm trying to vary the different modes that children } \\
\text { are interacting }\end{array}$ \\
\hline $\begin{array}{l}\text { I don't know if it's particularly a feature but um I } \\
\text { think that }\end{array}$ & I definitely think there are a lot of good elements \\
\hline well, my understanding I guess is... & we were devising all of the lessons \\
\hline $\begin{array}{l}\text { I can't really pinpoint anything, but I'm not entirely } \\
\text { sure }\end{array}$ & $\begin{array}{l}\text { so that's how we've been sharing a lot of our online } \\
\text { COVID-19 stuff }\end{array}$ \\
\hline to me, and I don't know if that's right & $\begin{array}{l}\text { so when I talk to the parents about that, they're } \\
\text { always really keen for the kids to be involved }\end{array}$ \\
\hline I don't know, what do you mean? & $\begin{array}{l}\text { our team worked together again for that, and we've } \\
\text { sent home procedures }\end{array}$ \\
\hline $\begin{array}{l}\text { I don't know, Do you have a list that I could choose } \\
\text { from }\end{array}$ & $\begin{array}{l}\text { yeah, I don't feel any pressure. I make it quite clear } \\
\text { at the start }\end{array}$ \\
\hline
\end{tabular}

Hedging, as a linguistic device, is a sign of powerless language (Blankenship \& Holtgraves, 2005) and used as a measure of vagueness (Jucker et al. 2003). However, in contrast, powerful language is the use of explicit emphatic responses (such as that shown in Table 1) used by people who are certain, confident and sure of themselves (Blankenship \& Holtgraves, 2005). The use of modality and hedging suggests participants either lack knowledge in the topic and/or are unwilling to commit to the statement of fact. Using the word probably functions as a modal adjunct of probability and is used to express speaker opinion as a middle ground between a definite no and a definite yes (Halliday, 2004).

Direct declarative statements of limited knowledge are also used by participants with I don't know, I'm not entirely sure. Here again, the language use demonstrates the limited knowledge and uncertainty a participant has. The addition of the adverb entirely in this example, hedges their response and takes the middle ground in the cline of knowledge. The word entirely equates with complete or absolute. The participants are adding the negation not [don't] as a modal adjunct in mood (Halliday, 2004), which is important in texturing identity (Fairclough, 2003).

Teachers use self-inspection and contemplation (Foucault, 1997) with words such as I think and I feel. There is a tenuous balance between power and knowledge in participants' reflections when replying to questions where they feel out of their depth. The teachers use phrases to cover themselves with "that's what I think it is, I may be wrong 
here but, I think, that's my take on it anyway, I hope that's the right answer". There is a division in their reflections - a division within self (Foucault, 1997); as professionals they feel they should know the answers; however, they back themselves and protect themselves from judgement with supporting discourse markers and hedging.

On the other hand, more direct language choices are made by participants when discussing their decision making and practice during COVID restrictions. Direct realis statements with limited hedging suggest participants are more confident in their responses and are used to show their "commitment to truth" (Fairclough, 2003). In addition, adverbs of degree or intensifiers such as really, definitely, quite are used for emphasis and increase the degree of emotional impact which strengthen the intent of the speaker (Parrott, 2010). These mood adjuncts serve to demonstrate a degree of finality and totality (Halliday, 2004) - participants are confident in their decisions and want the hearer to understand their standpoint and decision making.

The word so is used by participants as a causal semantic relation of consequence, and because is used as a semantic relation of reason (Fairclough, 2003) to demonstrate issues arising in their work and to support the decisions they have made in planning, articulating and/or practice. For example, Mrs Roberts talks about using One Note with the students and making audio clips for them. She relates the reasoning being that her students need to hear her voice. This may be because they are still young, or it may be that the concept/s she was teaching required her to articulate for understanding. Either way, Mrs Roberts is confident in her planning and application of work decisions.

Similarly, participants use the quantitative word just in their discussions about decision making and practice. Just is a minimising word (Parrott, 2010) and participants are using it to minimise their work. For example, Mr Johannsen speaks about a grid of activities that was designed for his students and it was just emailed out to the parents; this comment shares a nonchalance with his audience about the requirements of his workload. He planned it and did it with no hype or ceremony about the successful outcome.

Additionally, demonstrating confidence in their decision making, planning and practice during COVID-19, the participants use adverbs of intensification such as really and quite which serve to strengthen the intent of their statements (Parrott, 2010). Mrs Roberts is talking about sending work to her students and connecting her students online with "it was a really good way of connecting all the kids" and Miss Holland talking about her connection with parents and parent confidence in her work with "I don't feel any pressure. I make it quite clear at the start".

The participants demonstrate a confidence in decision making and recognise their moral obligation to the social rules, their mode of subjection (Foucault, 1978), about what the 'good teacher', 'professional teacher' is and does. They know what needs to be done for their students and they do it.

\section{Learning new ways of communicating}

The teachers' recounts regarding learning new ways of communicating further established their positioning as sophisticated practitioners. Teacher participants 
shared learning new ways of communicating during the COVID-19 lockdown, not only for themselves, but for students, parents and families.

We had to learn this whole new OneNote. And for us as lower teachers, we didn't know OneNote. My kids had no idea what OneNote is. The parents didn't know what OneNote is - Mrs Roberts

The participants commented on the interaction between family and school as being a closer connection than before, about parents being more involved and learning how 'school was being done', about teacher input and various learning/teaching practices. For example, Mrs Roberts shares, "but now, I think they're [parents/families] a lot more educated about different styles of learning" and Miss Downey and Miss Marvel share:

when I talk to the parents about that, they're always really keen for the kids to be involved and like 'oh', you know, 'I didn't think they'd be capable of doing that', or 'didn't think they'd be able to do, you know, a dance, or a drama skit, and stuff like that - Miss Downey

...there's been a lot more parent communication in this time. I guess it's been kind of really cool to see parents involved in their children's learning in a whole new way, that they wouldn't usually be. So, I think there's been a lot of positives from it - Miss Marvel

Participants commented on different educational sites that previously would have been out of reach for them being freely accessible during lockdown. Many businesses opened access to their resources during lockdown as a way of sharing resources for teachers, parents and families, but also as a way of advertising. Both teachers and students benefited from this according to participants and the strategy seems to have been successful because various participants reflected on using the resources after the 'free' access is revoked.

...the stuff that I found was amazing. And I thought 'wow, I can be using this - Mrs Roberts.

We've found some really great phonics type videos and songs that we've all continued to use.... And we're actually planning to buy some of the books we've found through Oxford Owl - Miss Hemsworth.

Similarly, teachers voiced new ways of learning and interacting with students which made their work exciting, challenging, but rewarding, nonetheless. In addition, the ease of learning new ways of communicating and integrating this with their teaching practices during extreme disruption demonstrates the standard of sophistication of these practitioners.

\footnotetext{
I'm trying to vary the different modes that children are interacting.... - Miss Marvel

I definitely think there are a lot of good elements and there's been a lot of learning opportunities happening at the moment - Miss Marvel

we put up One Notes and stuff like that and or paper copies that the parents could come and get... - Miss Hemsworth
} 
...those videos...we are going to use them as a tool in the future of a ways of [sic] communicating to parents - Mr Johannsen.

It was a really good way of connecting all the kids, and so they could see each other - Mrs Roberts

While it was time-consuming, home learning made us really think about how we were delivering every message - Mrs Roberts

\section{Collaborative practice versus the institution - us vs them}

Representation of collaborative practice between teachers and between teachers and families is clear in the data, but accompanying this collaboration, a divide between the collaborators and the institution. Despite the divide, the teachers continue to demonstrate their sophistication and professionalism.

During analysis it is important to note the use of personal pronouns in a text (Fairclough, 2003). The personal pronouns in this data clearly demonstrate the constructed 'we' community which can often be "elusive, shifting and vague" (p. 150), however, in this case elaborate on the connection between teachers. The use of we, we've us, our, demonstrate the collaboration and close connection of the 'we' teacher community. In addition, social actors are represented with words such as teachers, parents, students, the group, two teachers, our teachers; they are named and classified. This personal classification humanises actors (Fairclough, 2003).

In demonstrating the collaborative 'we teacher community' other emotive words are used apart from personal pronouns. Words such as teamwork, coming together, group, sharing between teachers, really good relationship, involved, our teachers, our team, these two teachers, sharing, our teacher things, and teacher to teacher all reflect the close connection of the 'we' teacher community.

\footnotetext{
...we had to make it all happen quite quickly last term... there's more things like teamwork, coming $\underline{\text { together, }}$ cause[sic] it was a group project - Miss Marvel

I do like the idea of sharing some of our teacher things Miss Downey

A lot of other teachers have come on board [with using technology] and then there has been a lot of sharing between teachers happening, which has been pretty cool - Miss Marvel

our team worked together again for that, and we've sent home procedures...- Miss Holland Our teachers ... were really keen and will change it [the programme put out by the state government] to suit us a little bit more, which was really good... they would just revamp it a little bit - Mr Johannsen.

...these two teachers were very good at supporting us all the time with it - Mr Evans

Underlined and bold font indicate specific words explained in text
}

The teacher participants also used language which demonstrates the close connection between family, parent, student and teacher. Language of ownership such as my parents, our kids, connects the parent, family and student to the 'we' community of teachers.

no, I don't have any pressure from parents, I've got actually a really good relationship with my parents - Miss Holland 
The linguistic choices made by participants share the collaboration and connection between fellow teachers and parents/students/families further demonstrating their sophistication in practice. However, the key to meaning in language is difference (de Saussure, 1959) and is highlighted when focussing on the 'we' community. As Foucault shared, we also need to focus on 'things unsaid' (Foucault, 1972) in order to make meaning. In this instance, the 'unsaid' is the difference, the 'other' - that which is not us, we, our therefore, the 'them'. The use of hyponymy -meaning inclusion, synonymy - meaning identity and antonymy - meaning exclusion, all lexicalise the discourse of the collaborative 'we' community as well as the 'them' or 'other' community (Fairclough, 2003).

The underlying, hidden and/or 'unsaid' things noticeable in teachers' linguistic choices show a variety of different ways of referring to the institution, 'the other' or 'them'. For example, Miss Marvel, when talking about choices to make when sending learning home for students, shares:

It was like 'What's the right thing to, what's the right video to fit what they're saying'? - Miss Marvel

Here she uses the words "the right thing to... the right video". What is 'unsaid' here is the opposite of right, 'what is the wrong thing, the wrong video?'. It may be that Miss Marvel is talking about the wrong thing/video for the teaching she is planning for, or it may be that the institution will not accept her choices of video or way of communicating or teaching her students. The audience is still aware of the divide in this statement.

...because it's expected to be done collaboratively with the parents - Miss

Downey (on assessment)

Here Miss Downey uses the word expected which tells the audience that there is a pre-determined obligation; that 'the other' - the assumption being the institution - requires collaboration between parents and teachers. The verbalisation that participants share demonstrates their self-examination with regard to the rules; the rules of being the 'good teacher' and doing what is expected from the institution and what is the right thing to do (Foucault, 1997). This language use clearly demonstrates the professionalism and sophistication of the participants in their practice. The divide between the 'we' community and 'them' community is also evident in power inequities discussed below.

\section{Power inequities}

A clear representation in the data is power inequities. These power inequities exist between institution and teachers, between schools which have access to digital technologies and those who do not, and between students who have parents who can help at home during lockdown and those who cannot. However, mostly teachers refer to the power relationship between themselves and the educational institution. Many of the comments are not malicious statements, further highlighting professionalism and 
Table 2 Representations: permission and restriction

\begin{tabular}{|c|c|}
\hline Permission & Restriction \\
\hline Allow us & No deviation \\
\hline Allowed & Absolutely no integration \\
\hline Get permission & Put a complete ban on it \\
\hline No, I can't do that & Education Qld said no \\
\hline I couldn't do it & There was nothing \\
\hline We couldn't do it & We had nothing \\
\hline We couldn't presume & Our school didn't have the platform \\
\hline Not an approved education departmental thing & 'Bring your own device' program \\
\hline \multirow{13}{*}{$\begin{array}{l}\text { We've got a boss that says no, you have to } \\
\text { cover the content }\end{array}$} & We couldn't presume \\
\hline & Just wouldn't cope \\
\hline & It just didn't have the capacity \\
\hline & We didn't do a lot \\
\hline & $\begin{array}{l}\text { We didn't use it and we didn't use google slides or any } \\
\text { of those }\end{array}$ \\
\hline & We didn't have time \\
\hline & It was sort of our own time and our own resources \\
\hline & That's one good way to get teachers off-side \\
\hline & $\begin{array}{l}\text { There's still that those targets [department requirements } \\
\text { and benchmarking] haven't shifted }\end{array}$ \\
\hline & $\begin{array}{l}\text { We do more and more and more our job gets bigger and } \\
\text { bigger and bigger }\end{array}$ \\
\hline & But you can do it in a way that suits you \\
\hline & They give us plenty of things to do \\
\hline & We've got enough to do with our own curriculum \\
\hline
\end{tabular}

sophistication in practice, but become visible in the data when analysis takes place. A main theme that emerged was permission and restriction.

Table 2 demonstrates the binaries that emerge in the data. When focussing on permission it is clear to see words such as allow, allow us, permission, can't, couldn't, no, approved all demonstrate the link between consent and/or authorisation and prohibition and/or prevention. Additionally, when looking at the larger linguistic offerings with regard to restriction, the balance between limitation and control is evident in the words no deviation, absolutely no integration, complete ban, there was nothing, we had nothing, didn't have the capacity, didn't use, didn't have time, to name a few. These linguistic data show the complexity of restriction that the teacher participants experience.

Intertextuality connects "one text to other texts, to the "world of text" " and brings other 'voices' into a text, in this case, the department of education (Fairclough, 2003 , p. 40). Some of the participants use intertextuality in referencing the Department of Education and their rules/regulations, for example, "Education Queensland said no, not an approved educational departmental thing, Queensland education" 
but also by using the more distancing personal pronouns they, them and assumed or 'backgrounded referencing' such as "it says that".

we were not allowed Zoom... my parents wanted to set up zoom sessions, but the Qld Education put a complete ban on it. So I even said that I would go home on my own computer on my day off and do it, and Education Qld said no. I can't do that. So for the lower school there was nothing. For the upper school, they had Seesaw, and not Zoom, but Microsoft Teams, so they use that. So for me, no, we had nothing... They [parents] were quite disappointed that I couldn't do Zoom... so we couldn't do it as an individual Zoom or connection. So our school didn't have that platform - Mrs Roberts

I think we're in a bit of a unique situation given the 'bring your own device' program... we couldn't presume that they all had a device - Mr Johannsen

...technically, you know it says that seesaw is not an approved education departmental thing so we didn't use it - Miss Hemsworth

If we use technology, so I have to get permission - Miss Downey

The participants also use negation to effect in their discussions which demonstrates the power relations and power inequality between the parties: no, not, didn't, can't, couldn't, nothing. As a linguistic entity, negation is employed to express truth values on a cline between negation and affirmation (Dahl, 1979; Swart, 2010) and often used to express speaker position (Martin \& White, 2003). Fairclough stresses that the use of negation can be used sincerely, ideologically or manipulatively in texts (1989). In this instance, the participants use negation when discussing restrictions and permissions sincerely, but with ideological undertones. They share with the researchers some of the frustrations they have encountered in not being able to do their jobs to the best of their abilities because of restrictions imposed upon them from the institution and broader society. These semantic relations between words described above often act as systems of classification and function as "unconscious instruments of construction" (Bourdieu \& Wacquant, 1992, p. 241). Participant lexical choices demonstrate that they are being constructed and classified according to Education policy boundaries, even when those boundaries restrict their practice.

Power in discourse is to do with "controlling and constraining the contributions of non-powerful participants" (Fairclough, 1989 p. 46). Here the institution is controlling and constraining subject positionings the teachers can occupy in their teaching practice by restricting their access to the students and their families.

\section{Discussion}

This study found the participants were knowledgeable and confident in decisions they were making in steering their teaching practice during the COVID-19 lockdown period. However, the teachers showed a division within themselves with reflections of self-doubt when discussing topics that they were unsure about. These reflections speak to current societal constructions and discourses - regimes of truth about 'the teacher' and 'teaching'. The participants were nervous about saying the wrong thing because then they may be further 'labelled' and classified as being 'bad' teachers.

In learning new ways of communicating, the teachers were working on themselves as a form of elaboration of ethical work (Foucault, 1978) in this instance, in 
building knowledge and expanding their repertoires of knowledge. In addition, they were spending time self-reflecting and self-examining aspects of themselves as well as aspects of their practice that can be improved upon. Many of the teachers were doing this as a form of responsibilisation; they were showing accountability to their students, the students' families and the wider community (Rose, 1999).

Society has classified and named teachers as 'good' and 'bad' and in so doing these subject positions have been normalised. This classification also divides. Teachers are under pressure to situate themselves on the right side of this classification at the best of times, but during the extreme situation of COVID-19, are now under more pressure to be seen as the 'good' teacher. Therefore, teachers are pushing themselves to learn new skills and ways of communicating in order to live up to societal expectation and constructions.

The study found that teachers were collaborating with each other despite the institutional boundaries. Teachers were working collaboratively because they wanted to position themselves and their students in the best light. The participants of this study were using capillary power to work collaboratively in order to produce effective/ engaging work for their students. They did this so that results from the inevitable future 'big data testing', will reflect positively on them and their practice.

Finally, power inequities were found to be evident in the data from this study. Power inequities are visible in participants' linguistic choices demonstrating that the teachers recognised and maintained the power differentials in action. Power is not only visible from the institution but reflected in social networks between teacher, institution, 'boss', parent/s, families and larger community - 'the social networks' (Foucault, 1982, p. 224).

The system of differentiation is layered with differences between: schools - private and state - those with access to digital technologies and those without; between teachers - those with access to and knowledge of digital technologies and those without; between students and families - those with access to and knowledge of digital technologies and those without; between students and families - those with access to time - those who can sit and work one-on-one with their children and those who cannot due to working commitments or family structure. However, even with these differentiations in place, the participants of this study showed sophistication in their practice.

Millions of families around the world have come to realise the importance of schooling as a face-to-face endeavour between teacher/facilitator and student and not just for childminding purposes. In addition, those families have also been reminded that 'educating' children is a very difficult venture which requires specialised knowledge and expertise.

Yes, the lockdown and disruption of 'ordinary' school days will have an impact on students and their learning, both negative and positive, but it is the authors' sentiment, that teachers are more artful at continuing quality education for their students, regardless of pitfalls. Society, (particularly the media) needs to be less judgemental of teachers and education professionals because, as the data from this limited study suggests, our participant educators are sophisticated practitioners who put their students' learning ahead of other concerns. These teachers are following outcomes of the report, Through growth to achievement: The report of the review to achieve 
educational excellence in Australian schools, (Australian Government, 2018) as discussed on page 5, which goes against the negative discourses about teachers of literacy in the broader social environment. The report details recommendations to improve school achievement and performance which these teachers have demonstrated: they use collaborative learning and teaching, they have tried to adjust their practices to include personalised learning and teaching based on the child's needs, they have planned collaboratively with fellow colleagues and they have taken part in mentoring and giving and receiving feedback.

\section{Conclusion}

As a society we need to reposition the constructed 'teacher' and the regimes of truth about teachers and teaching. This limited study demonstrates that some teachers of primary and early years literacy are sophisticated practitioners who are capable of fashioning competent teaching and learning opportunities despite institutional barriers and extreme disruptions such as a global pandemic.

Author Contributions All authors contributed to the study conception and design. Material preparation, data collection and analysis were performed by Dr Lynn Downes and Dr Deb Brosseuk. The first draft of the manuscript was written by Dr Lynn Downes and all authors commented on previous versions of the manuscript. All authors read and approved the final manuscript.

Funding Seed Grant Award funding from LLTT group QUT.

Data availability Not applicable.

Code availability Not applicable.

Declarations

Conflict of interest Not applicable.

\section{References}

Alhamdan, B., Al-Saadi, K., Baroutsis, A., \& Du Plessis, A. (2014). Media representation of teachers across five countries. Comparative Education, 50(4), 490-505. https://doi.org/10.1080/03050068. 2013.853476.

Australian Government (2018) Through growth to achievement: The report of the review to achieve educational excellence in Australian Schools. Available at: https://docs.education.gov.au/system/files/ doc/other/662684_tgta_accessible_final_0.pdf.

Australian Government (2020) 'First confirmed case of novel coronavirus in Australia' D. o. Health. Available at: https://www.health.gov.au/ministers/the-hon-greg-hunt-mp/media/first-confirmedcase-of-novel-coronavirus-in-australia.

Baker, J. (2020). Writing wrongs: 'Our society is about to hit a literacy crisis'. Sydney Morning Herald. file:///Users/lynndownes/Desktop/Literacy/Writing:debates/Writing\%20wrongs_\%20Our\%20society $\% 20$ is $\% 20$ about $\% 20$ to $\% 20$ hit $\% 20 \mathrm{a} \% 20$ literacy $\% 20$ crisis.htm

Baroutsis, A. (2015). Symbolic power, politics and teachers. Discourse Studies in the Cultural Politics of Education, 36(4), 610-618. https://doi.org/10.1080/01596306.2015.1011866. 
Baroutsis, A. (2016). Media accounts of school performance: Reinforcing dominant practices of accountability. Journal of Education Policy, 31(5), 567-582. https://doi.org/10.1080/02680939.2016.1145253.

Baroutsis, A., \& Woods, A. (2019). Academic research and public debates: A media analysis of the proposed phonics check. In A. Woods \& B. Exley (Eds.), Literacies in early childhood. (pp. 288-299). Oxford University Press.

Blankenship, K., \& Holtgraves, T. (2005). The role of different markers of linguistic powerlessness in persuasion. Journal of Language and Social Psychology, 24(1), 3-24. https://doi.org/10.1177/0261927X04 273034.

Bolton, R. (2019a). Boys' inability to write clearly is a new crisis in education. Financial Review. https:// www.afr.com/policy/health-and-education/boys-inability-to-write-clearly-is-a-new-crisis-in-education20190416-p51ek0\#: :text=Educators\%20say\%20they're\%20\%22stunned,substantially\%20less\%20cap able\%20than\%20girls.

Bolton, R. (2019b). Young kids better on reading, but writing skills are falling. Financial Review. https:// www.afr.com/policy/health-and-education/young-kids-better-on-reading-but-writing-skills-are-falling20190408-p51c27

Bourdieu, P., \& Wacquant, L. (1992). An invitation to reflexive sociology. . Polity Press.

Comber, B., Badger, L., Barnett, J., Nixon, H., \& Pitt, J. (2002). Literacy after the early years: A longitudinal study. Australian Journal of Language and Literacy, 25(2), 9-23.

Cope, B., \& Kalantzis, M. (2000). Multiliteracies: Literacy learning and the design of social futures. . Routledge.

Dahl, O. (1979). Typology of sentence negation. Linguistics. https://doi.org/10.1515/ling.1979.17.1-2.79.

de Saussure, F. (1959). Course in general linguistics (trans: W. Baskin). Philosophical Library.

Department of Education Tasmania (2016). Good teaching literacy 3-6. https://www.education.tas.gov.au/ students/school-and-colleges/curriculum/good-teaching-guides/. Accessed.

Dremel, A. (2014). Discourse and/as social practice - The analysis of the problem of resistance and hegemony. Mediterranean Journal of Social Sciences, 5(22), 155-166. https://doi.org/10.5901/mjss.2014. v5n22p155.

Edling, S. (2015). Between curriculum complexity and stereotypes: Exploring stereotypes of teachers and education in media as a question of structural violence. Journal of Curriculum Studies, 47(3), 399-415. https://doi.org/10.1080/00220272.2014.956796.

Fahey, G., \& Joseph, B. (2020). Parents' perspectives on home-based learning in the covid-19 pandemic. https://www.cis.org.au/app/uploads/2020/09/ap15.pdf

Fairclough, N. (1989). Language and power. . Longman.

Fairclough, N. (1992). Discourse and social change. . Polity Press.

Fairclough, N. (1995). Media discourse. . Edward Arnold.

Fairclough, N. (2001). The dialectics of discourse. Textus, XIV(2), 231-42. http://www.sfu.ca/cmns/courses/ 2012/801/1-Readings/Fairclough\%20Dialectics\%20of\%20Discourse\%20Analysis.pdf.

Fairclough, N. (2003). Analyzing discourse: Textual analysis for social research. . Routledge.

Fairclough, N. (2004). Interview with Norman Fairclough. Routledge. http://cw.routledge.com/textbooks/ 9780415874298/interview.asp.

Foucault, M. (1972). The archaeology of knowledge and the discourse on language (trans: A. M. Sheridan Smith). Pantheon Books.

Foucault, M. (1975). Discipline and punish: The birth of the prison (trans: A. M. Sheridan Smith). Vintage.

Foucault, M. (1977). The political function of the intellectual. Radical Philosophy, 17, 12-14.

Foucault, M. (1978). The history of sexuality. Volume 1: An introduction (trans: R. Hurley). Random House.

Foucault, M. (1980). Power/knowledge: Selected interviews and other writings: 1972-1977 (trans: C. Gordon, L. Marshall, \& K. Soper). Pantheon Books.

Foucault, M. (1982). The subject and power. In P. Rabinow \& H. Dreyfus (Eds.), Michel Foucault: Beyond structuralism and hermeneutics. The University of Chicago Press.

Foucault, M. (1988). Technologies of the self: A seminar with Michel Foucault. . Tavistock Publications.

Foucault, M. (1997). Ethics subjectivity and truth: The essential works of Michel Foucault 1954-1984. . The New Press.

Foucault, M. (1998). Polemics, politics and problematizations: An interview conducted by Paul Rabinow in May 1984. In P. Rabinow (Ed.), Ethics subjectivity and truth: The essential works of Michel Foucault. (pp. 1954-1984). The New Press.

Freire, P. (2009). Teachers as cultural workers: Letters to those who dare teach, with new commentary by Peter McLaren, Joe L. Kincheloe, and Shirley. Westview Press.

Halliday, M. A. K. (2004). An introduction to functional grammar. . Hodder Headline Group. 
Heckathorn, D. (2011). Comment: Snowball versus respondent-driven sampling. Socialogical Methodology, 41(1), 355-266. https://doi.org/10.1111/j.1467-9531.2011.01244.x.

Heffernan, A., Longmuir, F., Bright, D., \& Kim, M. (2019) 'Perceptions of teachers and teaching in Australia'. Monash University. Available at: https://www.monash.edu/thank-your-teacher/docs/Perceptionsof-Teachers-and-Teaching-in-Australia-report-Nov-2019.pdf.

Jucker, A., Smith, S., \& Lüdge, T. (2003). Interactive aspects of vagueness in conversation. Journal of Pragmatics, 35, 1737-1769. https://doi.org/10.1016/S0378-2166(02)00188-1.

Lakoff, R. (1975). Language and woman's place. . Harper \& Row.

Literacy Educators (2019) 'Over 180 literacy educators voice their concenrs over Dan Tehan's expert task force on reading' EduResearch Matters: A voice for Australian educational researchers. Australian Association for research in education. Available at: https://www.aare.edu.au/blog/?p=4938.

Liu, K., \& Fox Tree, J. (2012). Hedges enhance memory but inhibit retelling. Psychonomic Bulletin \& Review, 19(5), 892-898. https://doi.org/10.3758/s13423-012-0275-1.

Martin, J., \& White, P. (2003). Appraisal: The language of attitude and intersubjective stance. . Palgrave.

Meyers, K., \& Thomasson, M. (2020). Can pandemics affect educational attainment? Evidence from the polio epidemic of 1916. Cliometrica. https://doi.org/10.1007/s11698-020-00212-3 published online.

Mockler, N. (2013). Reporting the 'education revolution': MySchool.edu.au in the print media. Discourse Studies in the cultural politics of education, 34(1), 1-16. https://doi.org/10.1080/01596306.2012. 698860.

Mockler, N. (2020). Teachers don't deserve Morrison's guilt trip. The Sydney Morning Herald. Retrieved from https://www.smh.com.au/politics/federal/teachers-don-t-deserve-morrison-s-guilt-trip-20200416p54kec.html

Moss, J. (2016). 2014 Australian Association for Research in Education presidential address: Educational research and the tree of knowledge in a post human digital age. Australian Educational Researcher, 43, 505-525. https://doi.org/10.1007/s13384-016-0215-6.

Parrott, M. (2010). Grammar for English language teachers. . Cambridge University Press.

Queensland Government (2020). Learning@home. Department of Education. https://education.qld.gov.au/ curriculum/learning-at-home. Accessed.

Rose, N. (1999). Powers of Freedom. . Cambridge University Press.

Sahlberg, P. (2021). The epidemic Australia is failing to control. The Sydney Morning Herald. https://www. smh.com.au/education/the-epidemic-australia-is-failing-to-control-20201229-p56qq3.html?fbclid= IwAR1MSQQMWEGslcGF5e380iEBjKG-a2lkyjbKlmKz72JX15-3WlgYE9P78OU

Swart, H. (2010). Expression and interpretation of negation: An OT typology. . Springer.

Thomas, D. P., Emery, S., Prain, V., Papageorgiou, J., \& McKendrick, A. (2019). Influences on local curriculum innovation in times of change: A literacy case study. The Australian Educational Researcher, 46, 469-487. https://doi.org/10.1007/s13384-018-0295-6.

Thompson, G. (2016). Local experiences, global similarities: Teacher perceptions of the impacts of national testing. In B. Lingard, G. Thompson, \& S. Sellar (Eds.), National testing in schools: An Australian assessment. (pp. 57-71). Routledge.

Tuinamuana, K. (2011). Teacher Professional Standards, accountability and ideology: Alternative discourses. Australian Journal of Teacher Education, 36(12), 72-82. https://doi.org/10.14221/ajte.2011v36n12.8.

United Nations Educational Scientific and Cultural Organization (2020). COVID-19 educational disruption and response. https://en.unesco.org/themes/education-emergencies/coronavirus-schoolclosures.

Viner, R., Russell, S., Croker, H., Packer, J., Ward, J., Stansfield, C., et al. (2020). School closure and management practices during coronavirus outbreaks inlcuding COVID-19: A rapid systematic review. The Lancet Child \& Adolescent Health, 4(5), 397-404. https://doi.org/10.1016/S2352-4642(20)30095-X.

World Health Organisation (WHO) (2020). WHO announces COVID-19 outbreak a pandemic. https://www. euro.who.int/en/health-topics/health-emergencies/coronavirus-covid-19/news/news/2020/3/who-annou nces-covid-19-outbreak-a-pandemic. Accessed.

Publisher's Note Springer Nature remains neutral with regard to jurisdictional claims in published maps and institutional affiliations. 